\title{
Developing a Preventive Gendered Participatory Approach to Prevent Sexual Harassment among Soldiers in Zambia
}

\author{
John Mwitumwa Matakala ${ }^{1 *}$, Mubiana Macwani ${ }^{1}$, Philimon Ndubani ${ }^{1}$, Annie Namakando- \\ Phiri $^{1}$ \\ ${ }^{I}$ Department of Gender Studies, University of Zambia, Lusaka, Zambia
}

*Corresponding Author: John Mwitumwa Matakala, Department of Gender Studies, University of Zambia, Lusaka, Zambia

\begin{abstract}
The aim of the thesis was to develop a Preventive Gendered Participatory Approach to Prevent Sexual Harassment among Soldiers through social action. The study was grounded on the philosophy of interpretivism and interpretivism phenomenology research design. Purposive and respondent driven sampling were used to come up with the desired sample size of 74 and the resultant data were collected through a dual research process. Data collection was achieved using both in-depth and focus group discussions. The findings were thermalized chronologically in line with research questions, which were on typologies, characteristics of harassers and availability and application of sexual harassment programmes and policies, before social action by selected victims. The findings on the typologies for the participants were verbal and non-verbal harassment for the females while verbal harassment was established from the males. The findings of the characteristics for both male and female victims were seen through gender discriminatory behavior. The findings on the availability and application of sexual harassment programmes and policies showed that there was none though there was a new gender desk in its infancy stage. As per requirement, the researcher proposed a recommendation, which was used by a selected gendered focus group team of victims who developed a 6 phased preventive gendered participatory approach for preventing sexual harassment among soldiers in Zambia. The findings showed that if sexual harassment was not put on check it would affect the gendered input of the victims at work. It is against this background a more practical and workable solution based on victims input has been adopted for implementation by military authorities.
\end{abstract}

Keywords: Developing a Preventive Gendered Participatory Approach, Sexual Harassment, Soldiers.

\section{INTRODUCTION}

Worldwide much has been documented on sexual harassment due to its existence and concerns by the agencies of United Nations (UNSC,2008; European Commission, 2006). Studies have shown that in military communities, major victims were females/males with junior ranks thereby ending at proposing recommendations (Gallagher, 2008; Davidson, 2013; Deschamps, 2015; Greyson, 2010 and Matakala, 2015). However, the identified theoretical/practical problem is that none of the studies developed a preventive gendered participatory approach to prevent sexual harassment through social action, using a dual research process. The dual research process uses study findings with recommendations based on the inquirer's perspective, with the intention of using them with the affected victims who solve their own problems (Egaden,2012).In order to address the identified knowledge gap of developing a preventive gendered participatory approach to prevent sexual harassment through social action that the proposed study intends to address. In order to address the identified knowledge gap of developing a preventive gendered participatory approach through social action standardized principles must be followed. The principles demand that pre-requisite questions must be answered such as types, characteristics of perpetrators and programs stopping the problem from participant experiences before transition into a five phased social action process with victims. This is through a selected focus group or panel discussion team(Egaden,2012).

\subsection{Statement of the Problem}

Despite empirical evidence being documented and reported on sexual harassment in military communities (Gallagher, 2008; Davidson, 2013; Deschamps, 2015; Greyson, 2010; and Matakala, 2015). None of the studies developed a preventive gendered participatory approach to prevent sexual 
harassment preventive among soldiers through social action, using a dual research process .Hence a knowledge gap that the proposed study intends to address.

\subsection{General Objective}

To develop a preventive gendered participatory approach to prevent sexual harassment among soldiers through social action.

\subsection{Specific Objectives}

- Establish the typologies of sexual harassment before developing preventive gendered participatory approach among soldiers through social action

- Understand the characteristics of the harassers before developing a preventive gendered participatory approach among soldiers through social action

- Assess the availability and application of programs and policies of sexual harassment before developing a preventive gendered participatory approach among soldiers through social action

- Change the situation of sexual harassment through social action.

\subsection{Research Questions}

- What are the typologies of sexual harassment before development of a preventive gendered approach among soldiers through social action?

- What are the characteristics of harassers before the development of a preventive gendered participatory approach among soldiers through social action?

- Are the programs and policies of sexual harassment being applied before development of a preventive gendered participatory approach among soldiers through social action?

- How can sexual harassment be addressed among soldiers using social action?

\subsection{Significance Of The Study}

This study is ground breaking because it will develop a preventive gendered participatory approach to prevent sexual harassment among soldiers through social action. The innovation will further be forwarded to policy makers for practical implementation .It is also hoped that it will act as a stepping stone for further research.

\subsection{Ethical Consideration}

Ethical clearance was be obtained from the ethics

Committee of the University of Zambia. Thereafter, dual permission was sought involving the military authorities and the actual participants.

\subsection{Definition of Terms}

- Sexual harassment: Are the unwanted physical, verbal and nonverbal gestural action on a victim from the opposite sex

- Preventive gendered participatory approach: is a future practical way of trying to stop sexual harassment among male and female soldier's victims through focus group discussion guided by researcher's findings and proposed recommendations.

- Gendered experiences: A combination of Female/Male victims and their stories

\section{Methodology}

A qualitative research approach was used grounded in the philosophy of Interpretivism in order to understand the experiences and interpretations of sexual harassment among soldiers .The research design that was used was the Interpretivism phenomenogy to get down to the experiences of the participants as well as allowing the researcher to give meaning to the findings as opposed to bracketing his ideas by only getting views of participants. 
The study was conducted in military areas among soldiers that had experienced sexual harassment in Zambia. Purposive and the Respondent driven sampling were used to come up with the desired sample size of 74.The resultant data were collected through a dual research process of social action. The dual research process involved answering of pre requisite questions and a social action question in a group using the researcher's recommendations.

In order to collect information through the dual research process in-depth and focus group discussion interviews were used.

The findings were thematised chronologically in line with the first pre requisite questions which were on typologies, characteristics of harassers and availability and application of programs and policies of sexual harassment before social action. Data collection was preceded by a pretest in order to validate the collecting instruments .Furthermore issues of trustworthiness was achieved through Guba's four trustworthy strategy of credibility, dependability, transferability and conformability

\section{FINDINGS AND DISCUSSION}

\subsection{What are the Typologies of Sexual Harassment before Development of a Preventive? Gendered participatory Approach among Soldiers through Social Action?}

\subsubsection{Contextualized Similarities With Other Empirical Studies}

\begin{tabular}{|l|l|}
\hline $\begin{array}{l}\text { Empirical Findings on Typologies of Sexual } \\
\text { Harassment from Literature Review }\end{array}$ & $\begin{array}{l}\text { Research Findings on Typologies of Sexual } \\
\text { Harassment for this Study }\end{array}$ \\
\hline $\begin{array}{l}\text { Studies by Gallagher 2008; Davidson 2013; } \\
\text { McMillan 1993 and Matakala 2015 show that } \\
\text { the typologies of sexual harassment on female } \\
\text { service personnel with junior ranks were } \\
\text { verbal and non-verbal sexual harassment. }\end{array}$ & $\begin{array}{l}\text { The findings of this study are in agreement with } \\
\text { the other female studies in that it also found both } \\
\text { verbal and non-verbal sexual harassment. }\end{array}$ \\
$\begin{array}{l}\text { Furthermore a study by Greyson (2010) and } \\
\text { Seatle et al (2014) found the typology of } \\
\text { sexual harassment was verbal on male junior } \\
\text { ranks. }\end{array}$ & $\begin{array}{l}\text { The findings of this study also agree with other } \\
\text { male studies that verbal sexual harassment is the } \\
\text { typology of sexual harassment on male junior } \\
\text { soldiers. }\end{array}$ \\
\hline
\end{tabular}

Source: Field Data (2017) and Empirical Literature

This is what the participants had to say when asked what the typologies of sexual harassment are before social action;

A female soldier of the rank of private when asked on the typologies of sexual harassment before social action had this to say;

"Senior male soldiers tell us that imwe bakazi kulibe buffalo ikazi

Mwabwela kuononga nchito in chinyanja meaning you females

There is no female buffalo in our system of military have just

come to destroy our work in English....

A male soldier of the rank of lance corporal when asked on the typologies of sexual harassment before social action commented that;

"When I failed a class test and all females in class where above

Me a senior female soldier mocked me that I was a lady.......

\subsubsection{Contextualized Disimilarities with Other Empirical Studies}

This study did not come up with findings of physical sexual harassment for females and nonverbal sexual harassment for male soldiers respectively hence this was new knowledge contributed to the academia world unlike other studies. The reason for this difference is differential cultural backgrounds. 
3.2. What are the Characteristics of Harassers before the Developing of a 'Preventive? Gendered Participatory Approach" among Soldiers through Social Action

\subsubsection{Contexualised Similarities with Other Empirical Studies}

\begin{tabular}{|c|c|}
\hline $\begin{array}{l}\text { Empirical Findings on Characteristics of } \\
\text { Sexual Harasser from Literature Reviewed }\end{array}$ & $\begin{array}{l}\text { Research Findings on Characteristics of Sexual } \\
\text { Harassers for this Study }\end{array}$ \\
\hline $\begin{array}{l}\text { - Studies by Turchic and Susan (2010), Mills } \\
\text { (1992), Merriam (2015) and Mirriam (2012) } \\
\text { found that the characteristics of male sexual } \\
\text { harassers were patriarchal behavior, gender } \\
\text { discriminatory behavior and lack of } \\
\text { knowledge on sexual harassment behavior. }\end{array}$ & $\begin{array}{l}\text { - The findings of this study were similar to Turchic } \\
\text { and Susan (2010), Mills (1992), Merriam (2015) } \\
\text { and Miriam (2012) in terms of characteristics of } \\
\text { male sexual harassers being patriarchal behavior, } \\
\text { gender discriminatory behavior and lack of } \\
\text { knowledge on sexual harassment behavior. }\end{array}$ \\
\hline $\begin{array}{l}\text { - Empirical studies by Settle et al (2014) and } \\
\text { Greyson (2010) were gender discriminatory } \\
\text { behavior and abuse of authority behavioral } \\
\text { actions with regard to characteristics of } \\
\text { female sexual harassers. }\end{array}$ & $\begin{array}{l}\text { - The findings of this study were similar to Settle et } \\
\text { al (2014) and Greyson (2010) in that what was } \\
\text { established was gender discriminatory behavior } \\
\text { and abuse of authority behavioral action with } \\
\text { regard to characteristics of female sexual } \\
\text { harassers. }\end{array}$ \\
\hline $\begin{array}{l}\text { - In all cases these showed themselves in } \\
\text { different ways. }\end{array}$ & owed themselves in different ways in all \\
\hline
\end{tabular}

Source: Field Data (2017) and Empirical evidence

This is what the participants had to say when asked what the characteristics of the sexual harassers was before social action;

A male/female soldier when asked what the characteristics of sexual harassers was commented that;

"The characteristics of sexual harassers is seen from their gender

Discriminatory through some unwanted comments.............."

\subsubsection{Contextualised Disimilarities with Other Empirical Studies}

This study found cultural behavior from female responses and inferiority complex from male responses which was not established by other studies hence addition of new knowledge. The reason again was different cultural backgrounds.

3.3. Are the programs and Policies of Sexual Harassment being applied before the development of a preventive gendered participatory approach among soldiers through social action?

\subsubsection{Contextualised Similarities with Other Empirical Studies}

\begin{tabular}{|l|l|}
\hline $\begin{array}{l}\text { Empirical Findings on the Availability and } \\
\text { Application of Programmes and Policies of Sexual } \\
\text { Harassment }\end{array}$ & $\begin{array}{l}\text { Research Findings on the Availability and } \\
\text { Application of Programmes and Policies of } \\
\text { Sexual Harassment }\end{array}$ \\
\hline $\begin{array}{l}\text { The following empirical studies found that } \\
\text { there were no regulatory measures or } \\
\text { programmes that try to combat sexual } \\
\text { harassment with regard to female soldiers - }\end{array}$ & $\begin{array}{l}\text { This study came up with similar findings with } \\
\text { regard to female and male soldiers. }\end{array}$ \\
$\begin{array}{l}\text { Turchic and Susan (2010), Deschamps and } \\
\text { Mills (2015), Merriam (2015), Miriam (2012) } \\
\text { and Matakala (2015). }\end{array}$ & $\begin{array}{l}\text { that there were no programmes and policies on } \\
\text { sexual harassment to try and combat it. }\end{array}$ \\
$\begin{array}{l}\text { Further the following empirical studies found no } \\
\text { regulatory measure or programmes on sexual } \\
\text { harassment to combat it with regard to male } \\
\text { soldiers - Settle et al (2014) and Greyson (2010). }\end{array}$ &
\end{tabular}

Source: Field Data (2017) and Empirical Literature

This is what the participants had to say when asked on the availability and application of programs and policies of sexual harassment before social action: 
A male/female soldier of private rank when asked on the availability and applicability of programs and policies of sexual harassment had this to say;

"kulibiletu ali onse ma programs yalipo in chinyanja meaning

There are no programs on sexual harassment.what is there is

Is a Gender desk at Army headquarters

\subsubsection{Contextualised Disimilarities with Other Empirical Studies}

While the findings on the availability of programs of sexual harassment just like other studies showed that there were no programs this study however found that there was a gender desk at army headquarters though in its infancy a response nut seen in other studies hence new knowledge. The reason is different sensitization levels on gender issues.

\subsection{How can sexual harassment be addressed among soldiers using social action?}

\subsubsection{Innovation Creation Using Victims through Social Action}

Having established the findings to the prerequisite questions above as per social action principles the researcher proposed the recommendation in form of a question (How can we develop a curriculum on gender to be learnt by soldiers in order to prevent sexual harassment as a recommendation practically?).The special gendered focus group gave divergent views to the researcher.

After reading through the findings, it was expected that the researcher gives meaning and interpretation to the findings. While the researcher bracketed his pre-conceived ideas throughout the special gendered focus group discussion, this time around was at liberty to give meaning to the findings. This dual action fits into the interpretive phenomenology, which is also called the Heiddegerian Phenomenology. Its major proponent was martin Heiddger (Egaden, 2012). This strategy emphasises subjective interpretation of meanings of texts and is commonly used in legal studies were legal researchers tend to interpret texts in various legal documents especially statutes and case reports. In doing so, they read and scrutinize legal texts in order to give meanings contained therein with the purpose of facilitating the application of laws in a justifiable manner.

Furthermore, Theologians use the same strategy to explain and give meaning to biblical text in light of the present happenings. Similarly, Feminist Researchers who try to bring social change by transforming gender power relations such as sexual harassment through social action give meaning to findings of the participants (Egaden, 2012). It is against this background that the researcher used the same strategy, which is also known as Hermeneutic to come up with a " 6

Phased Preventive Participatory Approach to prevent sexual harassment among soldiers in Zambia." He went on to give meaning to the identified.

\subsubsection{Phased Preventive Gendered Participatory Approach to Prevent Sexual Harassment} among Soldiers in Zambia.

\begin{tabular}{|c|}
\hline $\begin{array}{l}\text { INITIATION - PHASE } 1 \\
\text { Developing a Gender Curriculum from relevant organization such as University of Zambia, } \\
\text { Ministry of Gender by Gender Desk at Army }\end{array}$ \\
\hline $\begin{array}{l}\text { DISPERSION - PHASE } 2 \\
\text { Resultant gender Curriculum, which includes a component of Sexual Harassment taken to } \\
\text { Military Schools }\end{array}$ \\
\hline $\begin{array}{c}\text { EXPANSION - PHASE } 3 \\
\text { Gender Desk to be given the status of a Directorate and Decentralize to all Levels of Command }\end{array}$ \\
\hline $\begin{array}{l}\text { DIFFUSION - PHASE } 4 \\
\text { Focal Point Persons at all Levels of Command to come } u \text { with a day of Sexual Harassment } \\
\text { Sensitization. }\end{array}$ \\
\hline $\begin{array}{l}\text { PERPETRATOR CONVERSION - PHASE } 5 \\
\text { Focal Points to use Victims in identifying the perpetrators. Convert one and let them convert } \\
\text { three through a Uranium Propelled Approach. }\end{array}$ \\
\hline $\begin{array}{l}\text { ARMY SENSITISED PHASE } 6 \\
\text { Soldiers are enlightened on issues of Sexual Harassment. Ceiling Point little penetration new } \\
\text { cases, hence Preventive Stage }\end{array}$ \\
\hline
\end{tabular}




\subsubsection{Explanatory meaning of the 6 Phased Preventive Gendered Participatory Approach for Prevention of Sexual Harassment among Soldiers in Zambia}

\section{a) Initiation Phase}

This is where the gender desk at Army headquarters is tasked to develop a gender curriculum related to the military. This must include an article of sexual harassment. The material is to be sourced from organizations such as the United Nations Gender Desk, University of Zambia, Gender Department, Ministry of Gender and the Zambia National Lobby for Women. In this way the gender desk will bring an inclusive military gender curriculum.

\section{b) Dispersion Phase}

This phase picks from the initiation phase a developed military gender curriculum. This task here is to take the curriculum for approval through the operations and training branch. Once the approval is done, the curriculum is sent to the various Military Schools beginning with Military Training Establishment of Zambia (MILTEZ). MILTEZ will prepare a pilot class whose certification should be accredited to the University of Zambia (UNZA). The curriculum must be further distributed to other schools, which should include all Recruit Training Centers (RTC), Special Forces School, Staff College and all other schools that will be deemed necessary.

\section{c) Expansion Phase}

This phase picks from the dispersion phase where a curriculum is utilized to have a pilot class graduate for military gender specialists on issues of sexual harassment. In order to welcome this large group, the gender desk at Army Headquarters needs to be given the status of a Directorate. Since the new directorate will involve sensitization through teaching, it should be under that umbrella together with the education directorate under a Brigadier General. The new directorate should ensure that it decentralizes power at every level of command to be filled in by the incoming pilot class of gender military specialists on sexual harassment sensitizations. The various levels of commands begin with Army Brigade, Battalion, Company and Platoon levels respectively.

\section{d) Diffusion Phase}

This phase picks from the expansion phase in that it absorbs the pilot class, graduates as gender focal point officers and warrant officers at all the levels of command. The task of the focal points is to lobby for a day of sensitization on issues of sexual harassment before soldiers proceed to their various tasks. Just like the Chaplaincy Corp does its job, the message to be given should be that it is bad and people need to refrain by knowing the typologies of sexual harassment. It should ensure that regulatory measures are written together with stakeholders such as legal representatives and chaplain representatives. These should also be read so that the message diffuses faster.

\section{e) Perpetrator Conversion Phase}

This phase picks from the diffusion phase where typologies of sexual harassment and policies and programmes of sexual harassment are read and absorbed by all soldiers upon sensitization. Once that is done, the focal point persons are to use the victims in identifying the perpetrators who are counseled with a view of converting them. One each perpetrator becomes a convert, they should convert three and the process should continue until all are sensitized. This strategy is called the Uranium propelled Approach. One atom splits three and the process continues until a wider area is covered. Albert Einstein used this formula when developing the Atomic Bomb through the Uranium element (Becker, 1975).

\section{f) Army Gender Sensitised Phase}

Once this phase is attained, there will be equal chances given to women soldiers in terms of combat appointments. This will assist in their reporting mechanism. This acts as the ceiling point because soldiers are enlightened and very few will commit the offences. At this new cases are prevented at the entry point, which are various training centers. Once the researcher had given meaning to the findings of the specialized gendered focus group team, he called the group for adoption of the 6 phased 
preventive gendered participatory approach for prevention of sexual harassment among soldiers. All the soldiers voted that the innovation be adopted

\section{CONCLuSion}

This thesis is important because it bridges the gap in knowledge with other studies that ended by proposing recommendations from the researcher perspective in order to solve sexual harassment problems. The study went ahead to use the recommendation to develop the 6 phased preventive gendered participatory approach to prevent sexual harassment among soldiers through social action. The process was in two parts. The first part in line with the research principles was to give answers to pre-requisite questions before development of the preventive gendered participatory approach through social action. The prerequisite questions were on typologies, characteristics of sexual harassers and availability and application of sexual harassment programmes and policies. This was done through in-depth and focus group discussion interviews (Egaden, 2012).

\section{ACKNOWLEDGEMENT}

I wish to thank my supervisors Prof. Macwang'i and Dr Ndubani for the guidance in this PhD research proposal. I further thank Dr Anne Phiri and all the Lecturers in the Department of Gender Studies for their advice. I also thank the Army Commander General Paul Mihova and Brig General Francis Kasempa from Special Forces (Commando) and the rest of Command at different levels for their support and blessings.

\section{REFERENCES}

[1] Becker, C. T.(1975). Advanced chemistry thought,Madisons publishers, London.

[2] Cresswell, J.W. (2007). Qualitative Inquiry and Research Designs: Choosing Among Five Approaches, $2^{\text {nd }}$ ed. Sage Publishers, London.

[3] Davidson, A. (2013). Military Sexual Harassment and Assault: Shameful Isn't Enough, The New Yorker Close Read Biog, New York.

[4] Deshamps, C. C. and Mills A F (2015) External Review into Sexual Harassment in the Canadian Armed Forces, Journal of social issues p687-702.

[5] Egaden S J, (2012).A Modern thought on advanced research and innovation: Developing of Toolkits and participatory action, penguin publishers, London.

[6] European Commission (2006); Sexual Harassment in the Work Place in the European Union. Directorate - General for employment industrial Relations and social affairs unity V/DS.

[7] Gallagher. G. (2008).Sexual Harassment and the US. Army: A Survey of Selected Military Academies, University of Kansa Publications, Kansas.

[8] .Giorgi, A et al. (1985), Phenomenology and Psychological Research Duquesne University Press, Pittsburg.

[9] Guba, I. and Lincolns (1994) Qualitative Research, Sage Publications, London.

[10] Hart, C. (2013). Doing a Literature Review: Release the Social Science imagination, Sage Publications, London.

[11] Kombo, D. K. and Tromp, L. A. (2006). Proposal and Thesis Writing: An Introduction, Pauline Publication Africa, Nairobi.

[12] Krueger, R. A. (1988). Focus Groups and Interviews: A practical Guide for Applied Research Methods. Sage Publishers, London.

[13] Leedy, A. and Ormrod, J. F. (2005). Practical Research Planning and Design. Merrill Prentice Publishers, New Jersey.

[14] Malekinejad M; Johnston L G; Kendall C; Kerr L R; Rifkin M R and Rutherford G W (2008) Using Respondent-Driven Sampling Methodology For HIV Biological and Behavioral Surveillance in International Settings: A Systematic Review. AIDS and Behavior, 12, S105-S130.

[15] Matakala, J. M. (2015).Sexual Harassment and Experiences of Female Soldiers on the UN Peace Keeping Operations, Dissertation, University of Zambia, Lusaka. 
[16] Turchik, J. and Susan, W. (2010). Sexual Harassment, Assault in the United States Military: A Review of Literature and Recommendations for the Future, Aggression and Violent Behaviour: Journal 266 - 277.

[17] UNSC, (2008). Challenges for the Deployment of United Nations Peace Keepers in Mission Areas, United Nations, New York.

\section{AUTHORS' BIOGRAPHY}

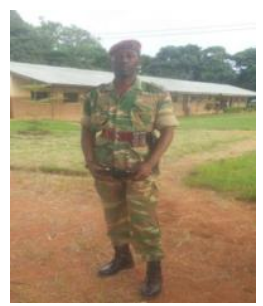

John Mwitumwa Matakala, the Phd Candidate in Gender Studies at the University Of Zambia. He is a Special Force Soldier in the Commando Uni

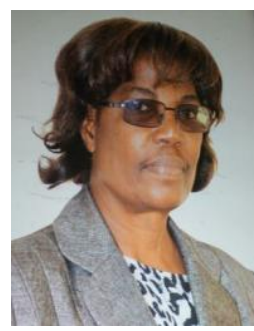

Prof. Mubiana Macwan'gi, Principal Supervisor of the Study, Institute of Economic and Social Research, University of Zambia, Director - 2010 to 2016. Senior Lecturer/Researcher - Department of Gender Studies

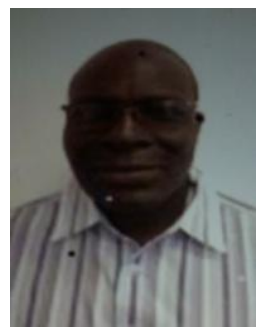

Dr. Philemon Ndubani, Co-Supervisor of the Study, Institute of Economic and Social Research, University of Zambia, Director - 2008 to 2010

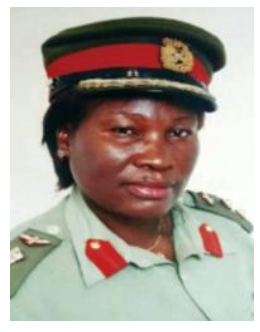

Dr. Annie Namakando Phiri (Rtd Col.), Co-Supervisor of the Study, the University of Zambia, Head of Department - 2013 to 2016. Senior Lecturer/Researcher - Department of Gender Studies

Citation: John Mwitumwa Matakala, Mubiana Macwani, Philimon Ndubani, Annie Namakando-Phiri. "Developing a Preventive Gendered Participatory Approach to Prevent Sexual Harassment among Soldiers in Zambia" International Journal of Humanities Social Sciences and Education (IJHSSE), vol 5, no. 2, 2018, pp. 9-16. doi: http://dx.doi.org/10.20431/2349-0381.0502002.

Copyright: () 2018 Authors. This is an open-access article distributed under the terms of the Creative Commons Attribution License, which permits unrestricted use, distribution, and reproduction in any medium, provided the original author and source are credited. 